\section{Godt og grundig om veiledning}

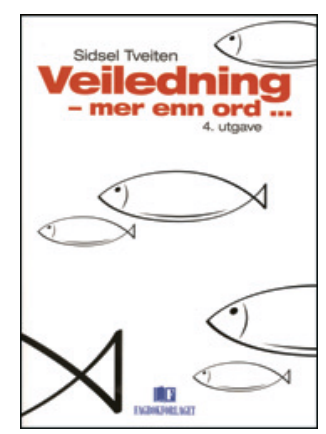

Sidsel Tveiten

Veiledning - mer enn ord

4. utg. 302 s, ill. Bergen: Fagbokforlaget, 2013.

Pris NOK 439

ISBN 978-82-450-1451-8

Forfatteren har bakgrunn som sykepleier og er førsteamanuensis ved Høgskolen i Akershus og Oslo. Boken handler om veiledning av studenter og fagutøvere i ulike funksjonsrettede fag og profesjoner, slik som sykepleiere, sosionomer, vernepleiere og lærere.

I første del omtaler forfatteren veiledning generelt. Målet med veiledning er økt mestringskompetanse. Veiledning er både faglig og personlig: faglig fordi søkelyset er rettet mot yrkesutøvelsen og egen praksis, personlig fordi dette i stor grad handler om den personen som utøver yrket eller praksis. Her kan jeg nevne et godt kapittel som klargjør veiledningens egenart opp mot tilgrensende områder som terapi, undervisning, rådgivning, evaluering, ledelse, coaching og flere. I et kapittel om etikk vektlegger hun at veiledning er et frivillig tilbud, og minner om veilederens makt. En viktig forutsetning for trygghet i veiledningen er plan og struktur, og hun beskriver hvordan oppstartsfasen, arbeidsfasen og avslutningsfasen i veiledningen kan være. Budskapet blir også understøttet av at forfatteren hele veien har med eksempler fra veiledningssituasjoner.

I den andre delen beskriver forfatteren praktiske metoder i veiledning. De fleste kan brukes både i en-til-en-veiledning og i gruppeveiledning. Først omtales dialog, som er veiledningens hovedmetode. Den skal hjelpe fokuspersonen til å gjøre sine egne oppdagelser eller erkjennelser. Det er viktig at veilederen lytter med oppmerksomheten rettet mot den andre, og ikke mot seg selv og egne assosiasjoner. Hensikten med dialogen er å skape økt felles forståelse av fokuspersonens anliggende, ikke å bli enig om noe eller finne løsninger.

Videre er det korte kapitler om en rekke praktiske metoder som kan brukes i veiledning, slik som opplevelsesnotat, dagbok, rollespill, gi og motta tilbakemelding og videoopptak. Denne delen kan brukes som oppslagsbok.

Språket er godt og klart. De mange eksemplene skaper gjenkjennelse og letter lesingen. I en tid der retningslinjer og prosedyrer får stor oppmerksomhet, er det viktig å bli minnet om at vi leger også må jobbe med vår personlige utforming av yrkesrollen. Her er veiledning, både i gruppe og en-til-en, til stor hjelp. For de av oss som er, eller vil bli, tungt involvert i veiledning og kurs for veiledere i eller utenfor sykehus er denne boken obligatorisk. For de fleste kolleger som har veiledning som en mindre del av sin kliniske hverdag, for eksempel i form av veiledning av en student, turnuslege eller lege i spesialisering, vil jeg anta at den blir for omfattende. Da anbefales heller Veiledning med leger under utdanning av Lycke, Handal og Lauvås (Gyldendal, 2005). Det kan også nevnes at Fagmedisinsk avdeling i Legeforeningen nylig har laget et nyttig hefte på 34 sider som heter Hva er god veiledning? En praktisk innføring $i$ veiledning av leger $i$ spesialisering $i$ sykehus. Det er en god start.

Sverre Lundevall

Fastlege og veilederkoordinator i Legeforeningen

\section{Nyttig supplement til Genesers lærebok}

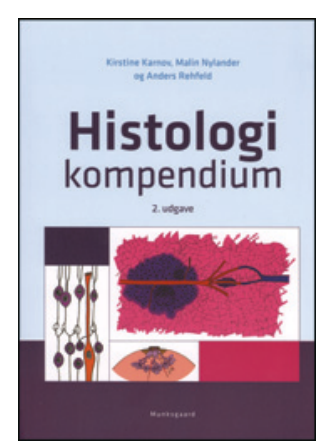

Kirstine Karnov, Malin Nylander, Anders Rehfeld Histologi kompendium

2. utg. 311 s, tab, ill. København: Munksgaard, 2013. Pris DKK 295

ISBN 978-87-628-1287-1

Denne andre utgaven av histologikompendiet er i likhet med første utgave ment som et supplement til og oppsummering av hovedpunktene i Genesers histologi (Munksgaard 2012). Sett i denne sammenhengen er den nyttig for medisinstudenter og andre helsefagstudenter som har histologi som et av hovedfagene i basal biologi.

Boken følger samme mal som Genesers lærebok. Inndeling i kapitler og underkapitler er den samme, og det henvises til figurer i denne læreboken med samme annotering, for eksempel fig 1.1 i kapittel 1 osv. Teksten er summarisk, ofte organisert i kulepunkter og sjelden i hele setninger, men er klar og illusterende. Nomenklaturen i histologi forutsettes kjent. Boken er systematisk og lett å finne frem $\mathrm{i}$.

Jeg kan anbefale boken primært til oppsummering av viktige sentrale poenger i vevslære og organlære på histologisk nivå. Den kan være spesielt nyttig ved repetisjon av histologien før eksamen i dette faget, men erstatter ikke større lærebøker. Den vil være praktisk som oppslagsverk for studenter og spesialister som benytter Genesers lærebok. Jeg vil likevel anbefale studenter som møter faget for første gang, om å lage sine egne notater i tillegg. Aktiv læring er en bedre læringsprosess enn å skumme gjennom ferdig bearbeidet materiale.

\section{Bent Rolstad}

Professor, Avdeling for anatomi

Universitetet i Oslo 